\title{
Comparison of Citrus tristeza virus (CTV) isolates by RFLP analysis of the coat protein nucleotide sequences and by the severity of the symptoms
}

\author{
Maria Júlia Corazza, Carlos Alexandre Zanutto, Maria Lúcia Zanineli-Ré, Gerd Walter Müller \& William \\ Mário de Carvalho Nunes
}

Núcleo de Pesquisa em Biotecnologia Aplicada, Universidade Estadual de Maringá, Av. Colombo 5790, Maringá, PR, 87020-900, Brazil

Author for correspondence: Carlos Alexandre Zanutto, e-mail: cazanutto@uem.br

\begin{abstract}
Plants of Pera sweet orange on Rangpur lime rootstocks, from orchards of the northwest and north of Paraná state, Brazil, were evaluated for severity of symptoms and genetic diversity of Citrus tristeza virus. The severity of symptoms was evaluated by the development of tree, fruit size and stem pitting symptoms. Isolates that infect these plants were compared with known mild and severe isolates by analysis of restriction fragments length polymorphism (RFLP) of the coat protein nucleotide sequences (CPNS), amplified by the polymerase chain reaction (PCR) and undergone digestion with the restriction enzymes Hinf I and Rsa I. The severity of symptoms showed that the analyzed plants from the northwest orchards presented mild to moderate tristeza symptoms, while the plants from the north orchards exhibited moderate to severe symptoms. The RFLP analysis revealed that the CTV isolates are constituted by haplotype mixtures. Rsa I was the enzyme that best discriminated the genetic diversity among the analyzed isolates of CTV. Two main groups were generated by the UPGMA analysis. The isolates from the northwest orchards grouped with most of the mild isolates used as control, and a great part of the isolates from the north orchards, was correlated with the severe isolate Capão Bonito. Correlation between the stem pitting intensity and RFLP patterns, was demonstrated with some exceptions. The failure of protection of some isolates and the contamination of the rootstocks by the severe isolates, in field nursery conditions, before grafting with scions with mild isolates, were the hypotheses considered to explain the occurrence of severe CTV isolates in the North area of Paraná State.
\end{abstract}

Key words: biological parameters of production, restriction enzymes, UPGMA.

\section{INTRODUCTION}

Citrus tristeza, caused by Citrus tristeza virus (CTV), is a disease with a high destructive potential, with devastating effects to citrus trees grafted onto sour orange (Citrus aurantium), in most areas in the world (BarJoseph et al., 1989; Moreno et al., 2008). In Brazil, due to widespread presence of its vector Toxoptera citricida Kirk, CTV is endemic.

As this virus is not a quarantine pest, it does not constitute a barrier to the commercialization of citrus propagative material in Brazil. Such fact has allowed the spread of citrus infected by severe or mild isolates all over the national territory, including the state of Paraná, which imports most of its nursery trees from the state of São Paulo (Morimoto, 1990).

In Paraná, recent studies of infected plants by CTV based on observations of symptoms (Nakatani et al., 1997), immune diagnostic and SSCP (single strand conformational polymorphism) analysis (Carraro et al., 2002), showed the presence of severe isolates of CTV in orchards of Pera orange in the northern regions of the state, demonstrating that clones of pre-immunized mother plants or naturally selected plants in other states not always behave satisfactorily in relation to tristeza.

Based on the above assumptions, this work was aimed at broadening the evaluation and comparison of severity of tristeza symptoms displayed by plants of different orchards from northern and northeastern Paraná, considering the origin of nursery plants (nurseries from São Paulo and Paraná states). In addition, RFLP (restriction fragment length polymorphism) was used to characterize CTV isolates from these orchards, establishing comparisons with mild and severe isolates from São Paulo state.

\section{MATERIAL AND METHODS}

\section{Origin of the CTV isolates}

The CTV isolates analyzed in this study were extracted from plants of Pera orange sampled at 34 localities, representing to commercial orchards in northwestern and northern regions of Paraná state (Table 1). Plants from orchards in the northwestern region were initially obtained from São Paulo state, and from 1991 onwards from "Pratinha" 
nursery (Atalaia, PR). Plants from orchards in the northern were obtained from the "CODAPAR" nursery (Companhia de Desenvolvimento Agropecuário do Paraná, Miraselva, PR), established in the years 1994 and 1997. Activities at the nursery have been interruped and nursery trees utilized in the northern region are now provided by two nurseries, namely: "Novo Mundo" (located at Sabáudia, PR) and "Pratinha".

The experiments were conducted with three replications per orchard, selecting whenever possible one non-symptomatic plant and two symptomatic plants for a total of 34 samples. As mild controls, the isolates I-349 (Itápolis, SP) (sample 16), Pera IAC (sample 17), I-111-D6 (CNPMF, Cruz das Almas, BA; sample 18), 1-89-Bianchi (FCA/UNESP, Botucatu, SP; sample 19) and I-59-Pera Vacinada (FCA/UNESP, Botucatu, SP; sample 20) were used. The isolates Capão Bonito (sample 21) and Barão B (sample 22) were used as severe controls.

\section{Evaluation of severity of tristeza symptoms in orchards}

The evaluation of symptom severity was performed by scoring plant size, plant vigor, fruit size, and presence of stem pitting in trunks and branches. For assessing the presence of stem pitting in branches, young twigs (aprox. $20 \mathrm{~cm}$ in length) were collected around the canopy of three plants per orchard. After the bark was removed from the twigs, stem pitting scores from 0 to 5 were given as follows: $0=$ no stem pitting, $1=1$ to 15 stem pits, $2=16$ to 30 pits, $3=31$ to 50 pits, $4=51$ to 80 pits and $5=$ surface entirely covered by stem pitting (Müller et al., 1996).

\section{Plant materials for molecular analysis}

Samples from selected plants were collected by taking leaves and young shoots of the four quadrants of each tree. The material was transported from the field to the laboratory in plastic bags, accommodated in polystyrene boxes with ice. After washing with tap water, the bark of the young shoots and the main leaf veins were lyophilized and stored in a freezer $\left(-20^{\circ} \mathrm{C}\right)$.

\section{Isolation and purification of the dsRNA}

The dsRNA was purified through two chromatography cycles in CF-11 cellulose column (Fibrosis Cellulose, Whatman) according to the procedure described by Valverde et al. (1990).

\section{Synthesis of complementary DNA (cDNA) by reverse transcriptase}

The quantified dsRNA served as template for the synthesis of the first cDNA strand, according to the procedure described by Sambrook et al. (1989). The synthesis was conducted in a thermocycler at $37^{\circ} \mathrm{C}$ for 2 hours.

\section{PCR-based amplification of coat protein (CP) nucleotide sequences}

The CP coding sequence was PCR-amplified with specific primers RFL33 (5' TCA ACG TGT GTT GAA
TTT 3') and RFL34 (5' ATG GAC GAC GAA ACA AAG 3'), derived from haplotype T-36 from Florida. The products of the amplification reactions were analyzed through electrophoresis in $1 \%$ agarose gels stained with etidium bromide and photographed under UV light in photodocumentation equipment.

\section{RFLP analysis}

The amplified CP fragments were digested with the restriction enzymes $\operatorname{Hinf} \mathrm{I}$ and $R s a \mathrm{I}$, incubated at $37^{\circ} \mathrm{C}$ for 3 hours. After digestion the samples were put in nondenaturing $8 \%$ polyacrylamide gels. The electrophoresis was done at $200 \mathrm{~V}$ for approximately 4 hours at $25^{\circ} \mathrm{C}$. The gel was stained with silver nitrate as described by Beidler et al. (1982).

The restriction fragments present in the gels were evaluated for all the CTV isolates as present (1) or absent (0) to produce a binary matrix data. The Jaccard coefficient was calculated to evaluate the genetic similarity and UPGMA (unweighted pair-group method with arithmetic averages) was used in order to group the CTV isolates (Rohlf, 1992).

\section{RESULTS}

The observation of selected trees in the orchards sampled in the northwestern and northern areas of Paraná state showed that, in general, they have a uniform pattern with vigorous and productive plants. However, stunted trees with apparent symptoms of tristeza were identified in orchards of both regions.

The intensity values of stem pitting in the trunks and branches of the fifteen analyzed plants in the northwestern orchards varied from zero to two, revealing mild to moderate symptoms of tristeza (Table 1). There was only a small difference between vigorous trees and dwarfed trees selected in each orchard in relation to the intensity of stem pitting.

Trunks and branches with no stem pitting symptoms (score zero) were observed in orchards located in Cidade Gaúcha and Floraí (northwestern region), regardless of plant age and origin. Mild or moderate symptoms of stem pitting (grades one and two) were found in some plants from those orchards and also from orchards located in Alto Paraná (northwestern region).

Differently from the northwestern region, the twelve plants analyzed from the northern orchards located in Rolândia and Nova América da Colina revealed moderate to severe stem pitting symptoms (Table 1). All plants from Rolândia orchards showed salient grooves on trunk and branches, with stem pitting scores of three or four. In the three orchards of Nova América da Colina, plants with good development displayed moderate stem pitting (scores of one or two), whilst the others presented typical severe tristeza symptoms (scores of three or four) (Table 1). 
Citrus tristeza virus isolates analyzed by RFLP...

TABLE 1 - Sites of sample collection of Pera sweet orange (C. sinensis L. Osb.) for evaluation of symptom severity of characterization of Citrus tristeza virus isolates in orchards from the northern and northwestern regions of the state of Paraná, Brazil

\begin{tabular}{|c|c|c|c|c|}
\hline Isolate & Region & Plant origin & Age (years) & Stem pitting score \\
\hline 1 & Northwest & Paraná & 8 & 1 \\
\hline 2 & Northwest & Paraná & 8 & 1 \\
\hline 3 & Northwest & Paraná & 8 & 2 \\
\hline 4 & Northwest & Paraná & 8 & 0 \\
\hline 5 & Northwest & Paraná & 8 & 1 \\
\hline 6 & Northwest & Paraná & 8 & 2 \\
\hline 7 & Northwest & São Paulo & 13 & 0 \\
\hline 8 & Northwest & São Paulo & 13 & 0 \\
\hline 9 & Northwest & São Paulo & 13 & 0 \\
\hline 10 & Northwest & São Paulo & 15 & 1 \\
\hline 11 & Northwest & São Paulo & 15 & 1 \\
\hline 12 & Northwest & São Paulo & 15 & 0 \\
\hline 13 & Northwest & Paraná & 13 & 0 \\
\hline 14 & Northwest & Paraná & 13 & 0 \\
\hline 15 & Northwest & Paraná & 13 & 0 \\
\hline 23 & North & Paraná & 10 & 3 \\
\hline 24 & North & Paraná & 10 & 4 \\
\hline 25 & North & Paraná & 10 & 4 \\
\hline 26 & North & Paraná & 10 & 1 \\
\hline 27 & North & Paraná & 10 & 4 \\
\hline 28 & North & Paraná & 10 & 4 \\
\hline 29 & North & Paraná & 7 & 2 \\
\hline 30 & North & Paraná & 7 & 3 \\
\hline 31 & North & Paraná & 7 & 4 \\
\hline 32 & North & Paraná & 7 & 2 \\
\hline 33 & North & Paraná & 7 & 3 \\
\hline 34 & North & Paraná & 7 & 3 \\
\hline
\end{tabular}

\section{RFLP analysis of CP nucleotide sequences}

The CP amplification products from CTV isolates collected in northern and northwestern orchards, as well as the mild and severe isolates used as controls, contained restriction sites for the two enzymes employed.

Digestion with Hinf I generated 12 fragments that varied from approximately 75 to $481 \mathrm{bp}$. The fragments of approximately $75,165,293$ e 344 bp were common to all CTV isolates. Polymorphisms between isolates were detected in fragments of approximately 106, 247, 264, 277, $311,327,401$ and $481 \mathrm{bp}$.

Only the mild control Pera Vacinada did not present the fragment of approximately $264 \mathrm{bp}$. On the other hand, the fragment of approximately $247 \mathrm{bp}$ was specific for this isolate. Fourteen RFLP electrophoretic patterns were observed, many of which grouped isolates from both regions combined with the different controls utilized.

The CTV isolates used in this study presented many restrictions sites for $R s a \mathrm{I}$, and 28 fragments with approximately 73 to $478 \mathrm{bp}$ were considered for analysis. All isolates from the northwestern region presented fragments of approximately 159,330 and $361 \mathrm{bp}$, which were also present in the majority of the mild controls, but absent in the severe controls and in the isolates of the northern region, except isolate number 28 which showed the $361 \mathrm{bp}$ fragment. Only isolates 28 and 32 from the northern region showed the 448 bp fragment, present in many isolates of the northwestern region and in some mild controls. Isolates from the northern region shared the majority of the fragments among them and with the severe control Capão Bonito.

Digestion with Rsa I generated 12 RFLP groups, indicating differences between isolates of the same region and between regions. Increased variability was identified among the isolates of the northwestern region, which presented five RFLP patterns, while in the northern region only two patterns were observed. The Pera IAC, Pera D6 and Pera Bianchi mild controls shared the same band patterns, whilst the Capão Bonito control presented similar electrophoretic pattern in relation to the majority of the northern region isolates. The Pera Vacinada and Barão B controls presented RFLP patterns different from the others. $R s a$ I separated the isolates from the two regions into distinct groups. The same did not occur with Hinf I.

The RFLP electrophoretic profiles generated by Hinf I and Rsa I indicated that any given CTV isolate from one plant is constituted by a mixture of many haplotypes. However, the use of the primers RFL33/RFL34 restricts haplotype diversity since haplotypes with mutations in the target sequence could not be amplified. This is not observed when degenerate primers are used (Gillings et al., 1993). 
The UPGMA analysis (Figure 1), generated by the Jaccard genetic similarity coefficient calculated from the data obtained with the digestion with Hinf I and Rsa I, showed that the Pera Vacinada and Barão B controls differed approximately $56 \%$ and $60 \%$ from the other isolates. The remaining CTV isolates were divided into two co-related large groups with a genetic coefficient of similarity of approximately $80 \%$. The first group includes all the isolates from the northwestern region, the Pera Itápolis, Pera IAC, Pera Bianchi mild controls, and isolate 28 from the northern region. The Capão Bonito severe control and the other isolates of the northern region are all in the second group. The first group was divided into many sub-groups correlated at approximately $83 \%$. In the second group, the Capão Bonito severe control and isolates 25,30 e 31 presented $100 \%$ genetic similarity and co-related approximately $93 \%$ with isolates $23,24,26,34,33$ e 27 , and approximately $86 \%$ with isolate 32 .

\section{DISCUSSION}

The data referring to the severity of symptoms of tristeza indicated that the analyzed plants from orchards in the northwestern region are infected by a mixture of CTV haplotypes from mild to moderate, while severe isolates, which induce stem pitting, are part of the viral complex present in plants analyzed in the northern region of the state of Paraná.

All plants in the northwestern region, even those that presented a reduced size and fruit production with smaller diameter, revealed mild to moderate symptoms of stem pitting. Probably, the characteristics displayed by these plants are not due to CTV severe haplotypes which are known to induce strong stem pitting symptoms. As considered by Ferguson and Garnsey (1993) and Powell et al. (1999), trees with decline symptoms can have its growth and development affected by other biotic or abiotic factors besides CTV infection. Trees from this region which originated from plants produced in nurseries from Paraná state did not differ, considering severity of tristeza symptoms, from those originated from the state of São Paulo.

The plants evaluated in the northern region presented variation in the severity of symptoms. Studies about stem pitting incidence in branches of Pera orange trees in this region were also carried out by Nakatani et al. (1997), indicating the variability in the intensity of this symptom among clones of this variety.

The CP sequence analysis with Hinf I and Rsa I revealed considerable variation in the $34 \mathrm{CTV}$ isolates analyzed. RNA viruses have a great potential for genetic variation due to their error-prone RNA replication, large populations, and short replication times (Rubio et al., 2001). These enzymes were also effective in detecting polymorphism in CTV isolates in other studies (Gillings et al., 1993; Valle et al., 2000; Roy et al, 2003). According to these authors the Hinf I enzyme provides better discrimination among the isolates. However, in our study, better discrimination among the isolates was obtained with $R s a \mathrm{I}$, despite the fact that twelve groups were constituted with this enzyme and fourteen with the $\operatorname{Hinf} \mathrm{I}$.

The CTV isolates from the northwestern region with mild to moderated stem pitting symptoms constituted a large RFLP group, correlating among themselves and

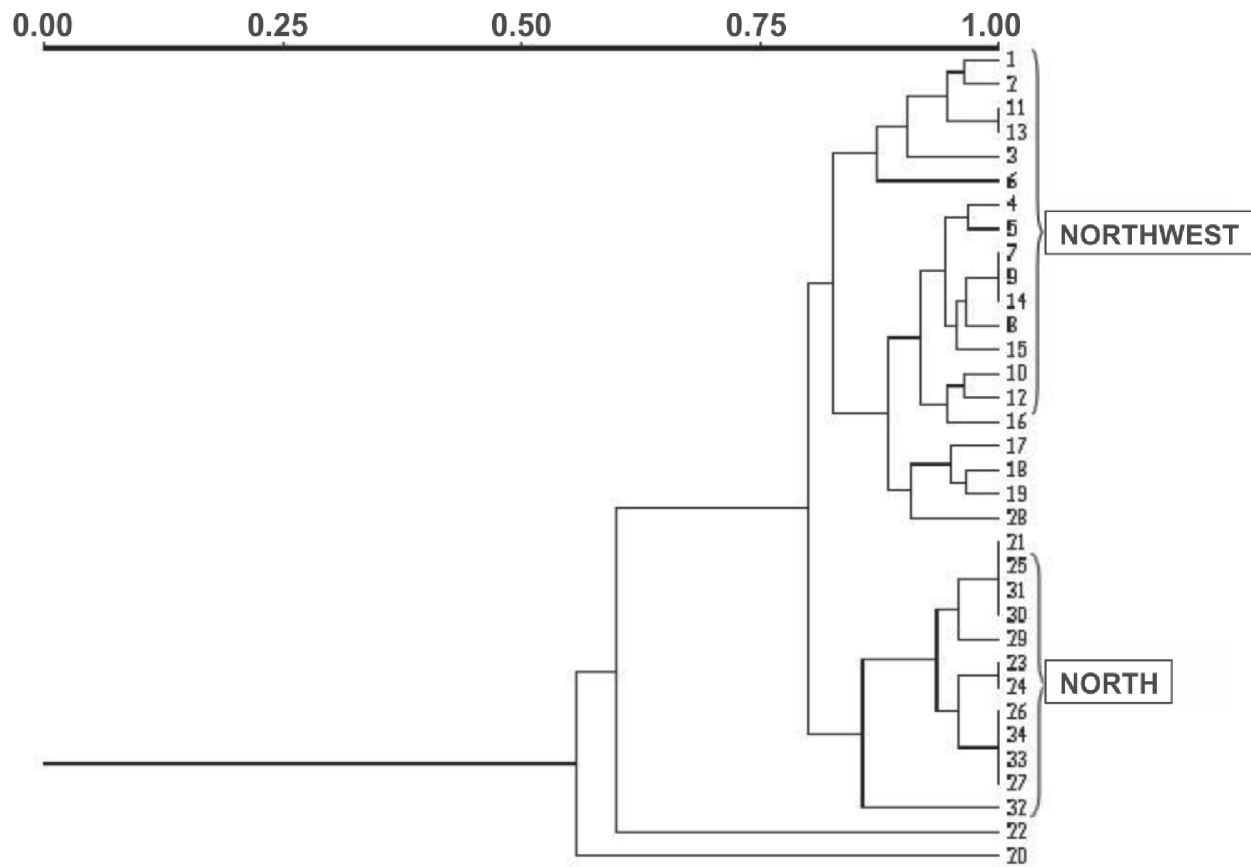

FIGURE 1 - Representative dendrogram of the CTV isolates grouping from differents plants and controls determinated by RFLP analysis of the coat protein nucleotide sequences (Jaccard Coefficient). Mild controls: 16, isolate I-349 (Itápolis, SP); 17, isolate Pera IAC; 18 , isolate I-111D6 (CNPMF, Cruz das Almas, BA); 19, isolate 1-89-Bianchi (FCA/UNESP, Botucatu, SP) and 20, isolate I-59-Pera Vacinada (FCA/UNESP, Botucatu, SP). Severe controls: 21, isolate Capão Bonito, and 22, isolate Barão B. 
with the majority of the mild isolates used as control. On the other hand, the majority of the northern region isolates obtained from plants with moderated to severe stem pitting symptoms appeared to be genetically similar to the Capão Bonito severe control, constituting a second large group.

The occurrence of severe CTV isolates in orchards of the northern region was also reported by Carraro et al. (2003), using immunodiagnosis with different monoclonal antibodies and SSCP patterns of the coat protein nucleotide sequence. However, in this investigation, some exceptions were observed. Three isolates obtained in orchards in this region, which presented mild to moderate stem pitting symptoms, grouped with the Capão Bonito severe control with similarity coefficients of approximately $96 \%$ (isolates 26 e 29) and $86 \%$ (isolate 32 ). Considering that plants from orchards in this region are 7 to 10 years old, they may not yet have expressed full stem pitting symptoms. According to Powell et al. (1999), many plants infected with severe isolates do not express symptoms for several years. In addition, the exact mechanism of interaction between the virus strain and the host genotype to produce the different degrees of symptoms is unknown; furthermore, the host type and certain environmental factors contribute to the induction of symptoms (Hilf et al., 1999; Roy and Brlansky, 2009).

Conversely, isolate 28 , obtained from a plant with severe stem pitting symptoms, grouped with isolates from the northwestern region and with the majority of the mild controls with approximately $90 \%$ similarity. Complete association between RFLP patterns and isolate severity could also not be demonstrated in the study of Valle et al. (2000). According to these authors this fact is due to the presence of several haplotypes in the same isolate. Besides, other regions of the genome must be associated with pathogenicity.

The above fact is consistent with the studies developed by Brlansky et al. (2003) and Velazquez-Monreal et al. (2009), who reported the selective transmission of components of the complex by the aphid vector, which was able to transmit severe strains present in a mild viral complex, or vice versa. The presence of hidden severe haplotypes within mild isolates was found in Australian, Floridian, and Corsican (France) isolates, and single aphid transmission was used as a tool for separation. The genotype profiles of three different Florida isolates were studied in three citrus hosts and the profiles did not change upon bud graft transmission (Broadbent et al. 1996; Brlansky et al. 2003; Brlansky and Roy, 2009).

Confirming the symptom severity data, molecular characterization through RFLP analysis of the CP nucleotide sequences also revealed that different CTV complexes infect the plants analyzed from orchards in the northwestern and northern regions of Paraná, distant from each other by approximately $300 \mathrm{~km}$. The differences observed between these two regions in relation to CTV diversity and severity of tristeza symptoms could be due to temperature. Some studies demonstrated that high temperatures can trim the severe symptoms of CTV or even inactivate the virus, while lower temperatures tend to accentuate symptoms (Müller, 1974). However, the annual average temperature in the two regions differs by only $1^{\circ} \mathrm{C}$ (Caviglione et al., 2000), which is unlikely to have caused the phenomenon observed.

The occurrence of severe haplotypes of CTV in orchards of the northern region can be attributed to at least two other factors, also considered by Carraro et al. (2003). The first would be the greater expression of severe components of the existing CTV complex in some of the introduced canopies, due to alterations of the physiological properties of the plants or environmental conditions. Another factor could be the mixture of haplotypes of CTV, resulting from the rootstock contamination by severe isolates in nursery conditions, before scion grafting (Müller et al., 1999; Rezende and Müller, 1995; Müller and Costa, 1971). This hypothesis is highly probable because the formation of plants in open-field nurseries was the main procedure adopted in the past.

\section{REFERENCES}

Bar-Joseph M, Marcus R, Lee RF (1989) The continuous challenge of citrus tristeza virus control. Annual Review of Phytopathology 27:291-316.

Beidler LL, Hilliard PR, Rill RL (1982) Ultrasensitive staining of nucleic acids with silver. Analytical Biochemistry 126:374-380.

Brlansky RH, Damsteegt VD, Howd DS, Roy A (2003) Molecular analyses of Citrus tristeza virus subisolates separated by aphid transmission. Plant Disease 87:397-401.

Broadbent P, Brlansky RH, Indsto J (1996) Biological characterization of Australian isolates of Citrus tristeza virus and separation by single aphid transmissions. Plant Disease 80:329333.

Carraro BP, Nunes WMC, Corazza-Nunes MJ, Machado MA, Stach-Machado DR (2003) Avaliação de complexos do Citrus tristeza virus da região Norte do Paraná por meio de testes imunológicos e SSCP do gene da capa protéica. Acta Scientiarum 25:269-273.

Caviglione JH, Kiihl LRB, Caramori PH, Oliveira D (2000) Cartas climáticas do Paraná - IAPAR. Available at: http://www.iapar.br/ modules/conteudo/conteudo.php?conteudo $=677$. Accessed on: 02/02/2004.

Ferguson JJ, Garnsey SM (1993) Citrus virus and virus-like diseases. University of Florida, Circular no. 1131.

Gillings M, Broadbent P, Indsto J, Lee R (1993) Characterization of isolates and strains of citrus tristeza closterovirus using restriction analysis of the coat protein gene amplified by the polymerase chain reaction. Journal of Virological Methods 44:305-317.

Hilf ME, Karasev AN, Albiach-Marti RM, Dawson WO, Garnsey SM (1999) Two paths of sequence divergence in the Citrus tristeza virus complex. Phytopathology 89:336-342.

Moreno P, Ambrós S, Albiach-Marti MR, Guerri J, Peña L (2008) Citrus tristeza virus: a pathogen that changed the course of the 
citrus industry. Molecular Plant Pathology 9:251-268.

Morimoto F (1990) Situação atual da Citricultura. In: Garcia Junior JB, Croce Filho J, Andrade JMB, Stenzel NMC, Leite Junior RP, Carvalho SLC (Eds.) $2^{\circ}$ Encontro Paranaense de Citricultura. pp. 51-56.

Müller GW, Costa AS (1971) Estudos sobre a interação entre o vírus da tristeza da copa e do porta enxerto. In: I Congresso de Fruticultura, Resumos. Campinas, SP. p. 463-473.

Müller GW, Costa AS, Kitajima EW, Camargo IJB (1974) Additional evidence that tristeza virus multiplies in Passiflora spp. In Proceedings of the $6^{\text {th }}$ Conference of the International Organization of Citrus Virologists - IOCV. Riverside, EUA. p. 7578.

Müller GW (1996) Pulgão e tristeza dos citros no Brasil. Laranja 17:292-293.

Müller GW, Targon MLN, Machado MA (1999) Trinta anos de uso do clone pré-imunizado 'Pêra IAC' na citricultura paulista. Laranja 20:399-408.

Nakatani AK, Pinto JHM, Leite Junior RP (1997) Avaliação de clones de laranja 'Pêra' em relação à tristeza dos citros na região norte do Estado do Paraná. In: $30^{\circ}$ Congresso Brasileiro de Fitopatologia, Resumos. Poços de Caldas, MG. Fitopatologia Brasileira 22 (Suppl.):338-340.

Powell CA, Pelosi RR, Rundell PA, Stover E, Cohen M (1999) Cross protection on grapefruit from decline-inducing isolates of Citrus tristeza virus. Plant Disease 87:989-991.

Rezende JAM, Müller GW (1995) Mecanismos de proteção entre vírus e controle de viroses de vegetais por preimunização. Revisão Anual de Patologia de Plantas 3:185-226.

Rohlf FJ (1992) Numerical taxonomy and multivariate analysis system version 1.70. Seatauket USA. Exeter Software.

Roy A, Ramachandran P, Brlansky RH (2003) Grouping and comparison of Indian citrus tristeza virus isolates based on coat protein gene sequences and restriction analysis patterns. Archives of Virology 148:707-722.

Roy A, Brlansky RH (2009) Population dynamics of a Florida Citrus tristeza virus isolates and aphid-transmitted subisolates: Identification of three genotypic groups and recombinants after aphid transmission. Phytopathology 99:1297-1306.

Rubio L, Ayllón MA, Kong P, Fernández A, Polek M, Guerri J, Moreno P, Falk BW (2001) Genetic variation of Citrus tristeza virus isolates from California and Spain: Evidence for mixed infections and recombination. Journal of Virology 75:8054-8062.

Sambrook J, Fritsh J, Manatis T (1989) Molecular cloning: A laboratory manual. $2^{\text {nd }}$ Ed. Cold Spring Harbor USA. Cold Spring Harbor Laboratory Press.

Valle VGR, Machado MA, Müller GW, Targon MLPN, TeofiloSobrinho J, Lee RF (2000) Characterization of citrus tristeza virus isolates by RFLP analysis of the coat protein gene. Fitopatologia Brasileira 25:175-181.

Valverde RA, Nameth ST, Jordan RL (1990) Analysis of double strand RNA for plant virus diagnosis. Plant Disease 71:255-258.

Velazquez-Monreal JJ, Mathews DM, Dodds JA(2009) Segregation of distinct variants from Citrus tristeza virus isolate SY568 using aphid transmission. Phytopathology 99:1168-1176.

TPP 248 - Received 4 February 2011 - Accepted 4 April 2012

Section Editor: Marcos A. Machado 